\title{
Potent Communication Skills in the Workplace: Perspectives from the Employers
}

\author{
Danebeth Tristeza Glomo-Narzoles Ph.D. ${ }^{1}$ \\ Department of Languages and Social Sciences, Center for General Education \\ AMA International University-Bahrain
}

\begin{abstract}
This study aimed to determine the potent communication skills in the workplace as perceived by the employers. A questionnaire was distributed to 64 employer representatives of companies/institutions/ organizations where the students are working or having their practicum/ on-the-job-training (OJT). Results revealed that the top potent communication skills in the workplace are as follows: reading and understanding work instructions and standard operating procedures; reading and comprehending letters and notices, electronic data, and email; reporting factual issues or incidents to the supervisor; demonstrating ability to listen effectively; and completing pertinent office forms, report sheets, tender documentation, work plans and specifications, incident report forms and notes. No significant differences were noted between the perceived communication skills in the workplace according to the type and sector of company/institution/organization where students are working or having their practicum/OJT.
\end{abstract}

Keywords: Communication Skills, Workplace Communication, Employers' Perspectives.

\section{INTRODUCTION}

Higher education institutions continuously strive to achieve quality and excellence in its tripartite functions which are instruction, research, and community engagement in order to produce graduates who are fully prepared to immerse in the world of work. Taking into consideration the needs of the industry, educational institutions also ensure that the knowledge and skills taught in the academe are aligned to the workplace needs and requirements.

A number of reports show that the top ten workplace skills encompass interpersonal, leadership, computer, problem solving, communication, time management, and mathematical, organizational, professional, analytical skills.

Surveys on the skills required by graduates conducted by Microsoft, the BBC, NACE, Target Jobs, and other organizations exemplified that teamwork, spoken and written communication, computing, language, and decision making skills, among others are regarded important by the above-mentioned companies and organizations.

The employability basic skills which include learning strategies, critical thinking, monitoring, mathematics, science, active learning and listening, reading comprehension, speaking, and writing were regarded pertinent according to the Secretary's Commission on Achieving Necessary Skills (SCANS) 1992 report, SCANS 2000 Report by America, and conclusions of a 2006 survey by the Conference Board to Human Resources Executives (in Smerd, 2007).

The National Association of Colleges and Employers 2007 Survey tagged communication skills and honesty and integrity as the graduates' most important skills and qualities.

The Quality Assurance Agency for Higher Education (2011) highlighted the $21^{\text {st }}$ century graduate attributes which include teamwork, collaboration, and leadership; life-long learning; research, scholarship, and enquiry; personal and intellectual autonomy; employability and career development; global citizenship; communication adeptness; information literacy; and ethical, social and professional understanding.

As such, the burden of producing graduates who are communicatively and linguistically competent is on the language teachers who ensure that the curricula, learning outcomes, and activities among others meet the workplace language needs. It is therefore deemed significant to gather employers' perspectives on the potent communication skills in the workplace. Hence, this study.

\subsection{Objectives of the Study}

This study aimed to determine the potent communication skills in the workplace as perceived by the employers.

Specifically, it sought to answer the following questions:

1.1.1. What are the top potent communication skills in the workplace as perceived by the employers?

\footnotetext{
${ }^{1}$ Corresponding Author: dtglomo@amaiu.edu.bh
} 
1.1.2. Are there significant differences on the most potent communication skills in the workplace when employers are classified as to the type of company/ organization/institution (education, IT, business, engineering, and medical) and sector (government or private)?

Based on the aforementioned problems, this null hypothesis was advanced:

There are no significant differences on the perceived potent skills in the workplace when employers were classified as to the type of company/organization/institution (education, IT, business, engineering, and medical) and sector (government or private).

\subsection{Research Paradigm}

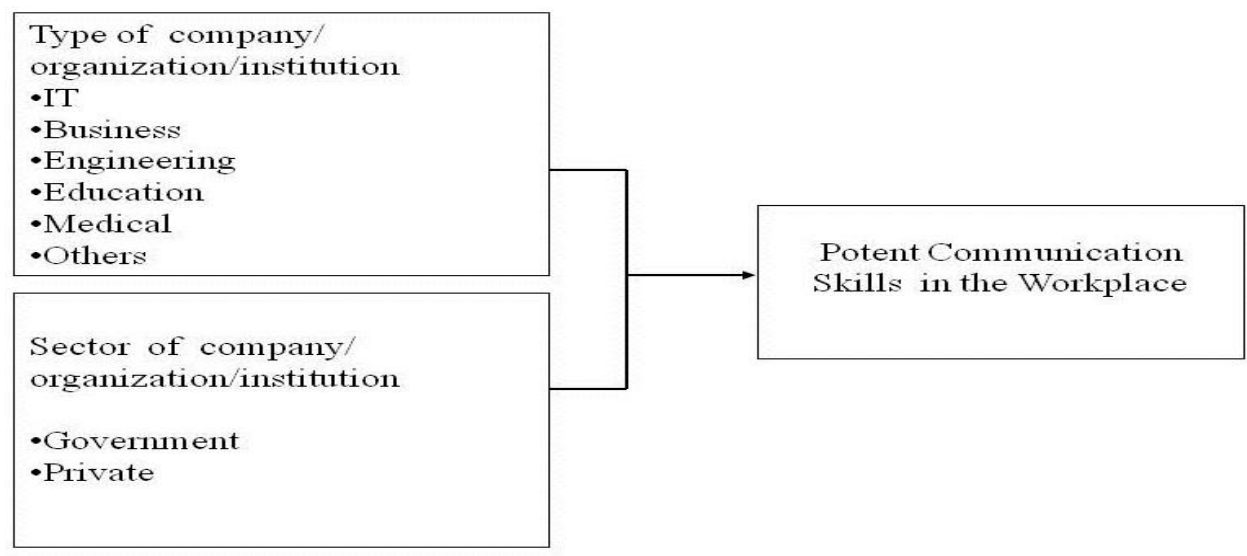

Fig2. The Research Paradigm

Figure 2 exhibits the paradigm of the study. This research aimed to determine potent communication skills in the workplace as perceived by the employers of companies/institutions/organizations where students are working or having their practicum/OJT.

\section{REVIEW OF RELATED LITERATURE AND STUDIES}

A number of studies reflect the significant impact of communication skills to achieve workplace efficiency and effectiveness.

In the study conducted by Robles (2012), results reveal that the top ten most important soft skills perceived by company heads are courtesy, responsibility, integrity, communication, social skills, professionalism, work ethics, teamwork, positive attitude and flexibility.

In the Kingdom of Bahrain, the Labour Market Regulatory Authority (LMRA) and the Employment Research Institute (ERI) Edinburgh Napier University, Scotland, in cooperation with Tamkeen, reported emerging findings from Bahrain's Labour Market Intelligence Project. This study aimed to gather feedback from the industry on the graduates' employability skills. Results revealed that graduates' skills needed by the industry comprised the ability to communicate, to participate in a team, to use their initiatives, to solve problems, and to think critically (Employability Skills Seminar, 2012).

These all confirm that communication skills are unswervingly regarded as the most essential attributes for workplace success. Apparently, communication is considered as the heart of any organization.

Communication skills, or the lack of these, can be a foremost cause of low morale and dissatisfaction. Employees who speak with respect, listen, handle conflict, and are heard in meetings are greatly appreciated by employers.

Bowman and Branchaw (in Csapo Featheringham, 2005) inquired from company executives and discovered that the psychology of business communication, oral communication, and fundamental language skills, were dubbed as the top aptitudes needed by tertiary education graduates.

Moreover, in a survey of Fortune (in Csapo Featheringham, 2005) to manufacturing companies, communication skills were found to be mainly vital, including listening, speaking, writing, reading, and negotiating.

However, numerous reports also divulge the communication skills deficiency of the university and college graduates. The National Endowment for the Arts (in Bonilla, 2008) disclosed that executives rated writing and 


\section{American Research Journal of English and Literature, Volume 1, Issue 5, 2015 ISSN 2378-9026}

reading to be the two deficiencies among newly-hired employees. They were also unable to read analytically, write effective business communication, compose without errors in grammar and spelling, and solve problems.

A report from the US Employment Policy Forum (in Bonilla, 2008) indicates that 70 percent of students applying for work are short of simple business and writing skills.

Moreover, in an article by Maslen, (2008), it was stipulated that Australian universities were noted to have allowed students whose first language is not English receive diplomas even without proficient communication skills. In so doing, the said graduates suffer from unemployment.

There are also a number of policies in Europe that emphasize the importance of language (Council of Europe, 2007) and underscore employability enhancement (Bologna Declaration, 1999; London Communiqué, 2007; Languages Mean Business, 2008).

ELAN (2006) likewise revealed that communication skills are significant features in the European economy.

Methodology

This descriptive research utilized an adapted Communication Skills in the Workplace questionnaire by Koncz (2012). This was distributed to 64 employer representatives of companies/institutions/ organizations where the students are working or having their practicum/ on-the-job-training (OJT).

Upon retrieval of the accomplished instruments, the data were processed, analyzed, and interpreted according to the requirements of the problems and hypotheses.

The mean, percentage, rank, t-test, and ANOVA were used in the treatment of the data gathered using the Statistical Package for Social Sciences (SPSS).

\section{RESULTS AND DISCUSSION}

Table1. Perceived Potent Communication Skills in the Workplace as an Entire Group

\begin{tabular}{|c|c|c|c|}
\hline Communication Skill & Mean & SD & Rank \\
\hline $\begin{array}{l}\text { 1. Reading and understanding work } \\
\text { instructions and standard operating } \\
\text { procedures }\end{array}$ & 4.48 & .71 & 1 \\
\hline $\begin{array}{l}\text { 2. Completing pertinent office forms, } \\
\text { report sheets, tender documentation, } \\
\text { work plans and specifications, } \\
\text { incident report forms and notes }\end{array}$ & 4.34 & .76 & 5 \\
\hline $\begin{array}{l}\text { 3. Comprehending verbal work } \\
\text { instructions from superv isors and } \\
\text { co-workers }\end{array}$ & 4.31 & 61 & 6.5 \\
\hline $\begin{array}{l}\text { 4. Discussing problems with others and } \\
\text { offering solutions and feedback }\end{array}$ & 4.22 & .86 & 8 \\
\hline $\begin{array}{l}\text { 5.Negotiating, bargaining, persuading, } \\
\text { and debating issues without being } \\
\text { unpleasant or abrasive to co-workers }\end{array}$ & 3.95 & 1.03 & 16.5 \\
\hline $\begin{array}{l}\text { 6. Demonstrating skills in the use of } \\
\text { language, grammar, and punctuation }\end{array}$ & 4.16 & .93 & 10.5 \\
\hline $\begin{array}{l}\text { 7. Organizing and presenting ideas } \\
\text { effectively for both formal and } \\
\text { spontaneous speeches }\end{array}$ & 4.08 & .82 & 12 \\
\hline $\begin{array}{l}\text { 8. Reading and comprehending } \\
\text { letters and notices, electronic } \\
\text { data and emails }\end{array}$ & 4.47 & .67 & 2 \\
\hline $\begin{array}{l}\text { 9. Demonstrating ability to } \\
\text { listen effectively }\end{array}$ & 4.36 & .78 & 4 \\
\hline $\begin{array}{l}\text { 10. Participating in meetings and } \\
\text { using interviewing skills to gather } \\
\text { information or feedback }\end{array}$ & 3.84 & 1.00 & 19.5 \\
\hline
\end{tabular}


American Research Journal of English and Literature, Volume 1, Issue 5, 2015

ISSN 2378-9026

\begin{tabular}{|c|c|c|c|}
\hline Communication Skill & Mean & $\mathrm{SD}$ & Rank \\
\hline $\begin{array}{l}\text { 11.Reporting factual issues or incidents } \\
\text { to the supervisor }\end{array}$ & 4.38 & 68 & 3 \\
\hline $\begin{array}{l}\text { 12. Utilizing proper gestures and } \\
\text { facial expressions when } \\
\text { communicating orally }\end{array}$ & 3.86 & .94 & 18 \\
\hline $\begin{array}{l}\text { 13. Understanding business, } \\
\text { computing, medical or engineering } \\
\text { lingo used in the workplace }\end{array}$ & 3.84 & .96 & 19.5 \\
\hline $\begin{array}{l}\text { 14. Writing appropriate forms of } \\
\text { business communication such as } \\
\text { letter, memorandum, report, } \\
\text { minutes of the meeting, plans, etc. }\end{array}$ & 4.00 & .91 & 14.5 \\
\hline $\begin{array}{l}\text { 15.Utilizing personal computer, multi- } \\
\text { mediafacilities, video, computer } \\
\text { graphics, projectors, devices, and } \\
\text { gadgets in communicating with } \\
\text { internal and external audiences }\end{array}$ & 4.00 & 1.11 & 14.5 \\
\hline $\begin{array}{l}\text { 16. Recognizing the benefits and } \\
\text { applications of memos, faxes, e-mails, } \\
\text { SMS, Internet to assist free-flowing } \\
\text { communication channels outside and } \\
\text { inside the organization }\end{array}$ & 4.17 & .88 & 9 \\
\hline $\begin{array}{l}\text { 17. Conducting research by gathering } \\
\text { information, interpreting data, and } \\
\text { presenting the results }\end{array}$ & 3.95 & .84 & 16.5 \\
\hline $\begin{array}{l}\text { 18. Making use of pictures, diagrams, } \\
\text { tables, charts, and other visual aids in } \\
\text { reports }\end{array}$ & 4.05 & 1.15 & 13 \\
\hline $\begin{array}{l}\text { 19. Entertaining queries and concerns } \\
\text { of clients and customers regarding the } \\
\text { products and services provided by the } \\
\text { company }\end{array}$ & 4.16 & .88 & 10.5 \\
\hline $\begin{array}{l}\text { 20. Speaking English clearly, fluently, } \\
\text { and accurately }\end{array}$ & 4.31 & .77 & 6.5 \\
\hline
\end{tabular}

Table 1 depicts the potent communication skills in the workplace as perceived by the employers. As an entire group, the employers considered the following skills to be significant: 1 . Reading and understanding work instructions and standard operating procedures $(M=4.48) ; 2$. Reading and comprehending letters and notices, electronic data, and emails (M=4.47); 3. Reporting factual issues or incidents to the supervisor ( $M=4.38)$; 4. Demonstrating ability to listen effectively $(\mathrm{M}=4.36)$; and 5. Completing pertinent office forms, report sheets, tender documentation, work plans and specifications, incident report forms and notes $(\mathrm{M}=4.34)$. 
American Research Journal of English and Literature, Volume 1, Issue 5, 2015

ISSN 2378-9026

Table2. Perceived Potent Communication Skills in the Workplace According to the Type of Company/Institution/ Organization

\begin{tabular}{|c|c|c|c|c|c|c|c|c|c|c|c|c|}
\hline Communication Skill & $\begin{array}{r}\mathbb{T} \\
\text { Meant }\end{array}$ & Rank & $\begin{array}{l}\text { Busit } \\
\text { Mean }\end{array}$ & & & $\begin{array}{l}\text { eering } \\
\text { Raank }\end{array}$ & $\begin{array}{l}\text { Educe } \\
\text { Mean }\end{array}$ & $\begin{array}{l}\text { ation } \\
\text { Rank }\end{array}$ & $\begin{array}{l}\text { Medi } \\
\text { Meann }\end{array}$ & $\begin{array}{l}\text { cine } \\
\text { Rank }\end{array}$ & $\begin{array}{l}\text { Oth } \\
\text { Mean }\end{array}$ & $\begin{array}{l}\text { eers } \\
\text { Rank }\end{array}$ \\
\hline $\begin{array}{l}\text { 1.Reading and understanding work } \\
\text { instructions and standard operating } \\
\text { Procedures }\end{array}$ & 4.86 & 1 & 4.52 & 3 & 4.50 & 5 & 4.20 & 12.5 & 4.50 & 7 & 4.31 & 9.5 \\
\hline $\begin{array}{l}\text { 2. Compl leting pertinent office forms, } \\
\text { report sheets, tender documentation, } \\
\text { work plans and specifications, } \\
\text { incidentreport forms and notes }\end{array}$ & 4.43 & 8.5 & 4.38 & 4.5 & 4.50 & 5 & 4.60 & 3.5 & 3.83 & 20 & 4.23 & 11 \\
\hline $\begin{array}{l}\text { 3. Comprehending verbal work } \\
\text { instructions from supervisors and } \\
\text { co-workers }\end{array}$ & 4.57 & 6 & 4.09 & 10 & 4.58 & 2 & 4.40 & 8 & 4.17 & 15 & 4.31 & 9.5 \\
\hline $\begin{array}{l}\text { 4. Discussing problems with others and } \\
\text { offering solutions and feedback }\end{array}$ & 4.57 & 6 & 4.19 & 6.5 & 4.50 & 5 & 3.60 & 17 & 4.33 & 10.5 & 4.00 & 13.5 \\
\hline $\begin{array}{l}\text { 5.Negotiating, bargaining, persuading, } \\
\text { and debating issues withoutbeing } \\
\text { unpleasant or abrasive to co-workers }\end{array}$ & 4.27 & 12 & 371 & 13 & 4.08 & 11.5 & 4.20 & 12.5 & 4.17 & 15 & 3.85 & 18.5 \\
\hline $\begin{array}{l}\text { 6. Demonstrating skills in the use of } \\
\text { language, grammar, and punctuation }\end{array}$ & 4.00 & 19 & 4.14 & 8.5 & 4.33 & 7 & 4.60 & 3.5 & 4.17 & 15 & 3.92 & 15 \\
\hline $\begin{array}{l}\text { 7.Organizing and presenting ideas } \\
\text { effectively for both formal and } \\
\text { spontaneous speeches }\end{array}$ & 4.14 & 16 & 3.86 & 12 & 4.14 & 9 & 3.80 & 16 & 4.33 & 10.5 & 4.33 & 7 \\
\hline $\begin{array}{l}\text { 8. Reading and comprehending } \\
\text { letters and notices, } \\
\text { electronic data, and emails }\end{array}$ & 4.71 & 3 & 4.87 & 1 & 4.71 & 1 & 4.60 & 3.5 & 4.67 & 3.5 & 4.67 & 2 \\
\hline $\begin{array}{l}\text { 9. Demonstrating ability to } \\
\text { listen effectively }\end{array}$ & 4.57 & 6 & 4.57 & 2 & 4.57 & 3 & 4.40 & 8 & 4.50 & 7 & 4.67 & 2 \\
\hline $\begin{array}{l}\text { 10. Participating in meetings and } \\
\text { using interv rewing skills to gather } \\
\text { information or feedback }\end{array}$ & 4.00 & 19 & 4.00 & 11 & 4.00 & 15.5 & 3.40 & 18 & 4.67 & 3.5 & 4.67 & 2 \\
\hline
\end{tabular}


American Research Journal of English and Literature, Volume 1, Issue 5, 2015

ISSN 2378-9026

\begin{tabular}{|c|c|c|c|c|c|c|c|c|c|c|c|c|}
\hline \multirow[t]{2}{*}{ Communication Skill } & \multicolumn{2}{|l|}{$\mathbb{T}$} & \multicolumn{2}{|c|}{ Business } & \multicolumn{2}{|c|}{ Engineering } & \multicolumn{2}{|c|}{ Education } & \multicolumn{2}{|c|}{ Medicine } & \multicolumn{2}{|c|}{ Others } \\
\hline & Mean & Rank & Mean & Rank & Mean & Rank & Mean & Rank & Mean & Rank & Mean & Rank \\
\hline $\begin{array}{l}\text { 11. Reporting factual issues or } \\
\text { incidents to the supervisor }\end{array}$ & 4.28 & 10.5 & 4.38 & 4.5 & 4.17 & 8 & 3.80 & 16 & 4.67 & 3.5 & 4.38 & 8 \\
\hline $\begin{array}{l}\text { 12. Jtilizing proper gestures and } \\
\text { facial expressions when } \\
\text { communicating orally }\end{array}$ & 4.14 & 16 & 3.47 & 16.5 & 4.08 & 11.5 & 4.60 & 3.5 & 4.00 & 18.5 & 3.85 & 18.5 \\
\hline $\begin{array}{l}\text { 13. Understanding business, } \\
\text { computing, medical or engineering } \\
\text { lingo used in the workplace }\end{array}$ & 4.14 & 16 & 3.47 & 16.5 & 4.00 & 15.5 & 4.14 & 13 & 4.14 & 17 & 3.85 & 18.5 \\
\hline $\begin{array}{l}\text { 14. Writing appropriate forms of } \\
\text { business communication such as } \\
\text { letter, memorandum, report, } \\
\text { minutes of the meeting, plans, etc. }\end{array}$ & 4.28 & 10.5 & 3.86 & 11 & 4.00 & 15.5 & 4.29 & 10.5 & 4.29 & 12.5 & 3.85 & 18.5 \\
\hline $\begin{array}{l}\text { 15.Utilizing personal computer, multi- } \\
\text { mediafacilities, video, computer } \\
\text { graphics, projectors, devices, and } \\
\text { gadgets in communicating with } \\
\text { internal and external audiences }\end{array}$ & 4.00 & 19 & 3.76 & 13.5 & 4.08 & 11.5 & 4.00 & 14 & 4.00 & 18.5 & 4.00 & 13.5 \\
\hline $\begin{array}{l}\text { 16. Recognizing the benefits and } \\
\text { applications of memos, faxes, e-mails, } \\
\text { SMS, Internet to assist free-flowing } \\
\text { communication channels outside and } \\
\text { inside the organization }\end{array}$ & 4.23 & 13.5 & 4.19 & 6.5 & 3.92 & 19 & 4.43 & 6 & 4.43 & 9 & 4.46 & 5.5 \\
\hline $\begin{array}{l}\text { 17. Conducting research by gathering } \\
\text { information, interpreting data, and } \\
\text { presenting the results }\end{array}$ & 4.23 & 13.5 & 3.71 & 15 & 4.08 & 11.5 & 4.29 & 10.5 & 4.29 & 12.5 & 4.15 & 12 \\
\hline $\begin{array}{l}\text { 18. Making use of pictures, diagrams, } \\
\text { tables, charts, and other visual aids in } \\
\text { reports }\end{array}$ & 4.71 & 3 & 3.76 & 13.5 & 3.92 & 19 & 4.71 & 1 & 4.71 & 1 & 4.15 & 4 \\
\hline $\begin{array}{l}\text { 19. Entertaining queries and concerns } \\
\text { of clients and customers regarding the } \\
\text { products and services provided by the } \\
\text { company }\end{array}$ & 4.71 & 3 & 4.14 & 8.5 & 3.92 & 19 & 4.40 & 8 & 4.50 & 7 & 3.84 & 16 \\
\hline $\begin{array}{l}\text { 20. Speaking English clearly, fluently, } \\
\text { andaccurately }\end{array}$ & 4.43 & 8.5 & 4.43 & 4 & 4.00 & 15.5 & 3.80 & 16 & 4.67 & 3.5 & 4.46 & 5.5 \\
\hline
\end{tabular}

Table2 shows the potent communication skills in the workplace according to the type of company/institution/ organization where students are working or having their practicum/OJT.

Employers from the IT companies ranked the following to be the most potent communication skills in the workplace: 1. Reading and understanding work instructions and standard operating procedures $(\mathrm{M}=4.86) ; 2$. Reading and comprehending letters and notices, electronic data, and emails, making use of pictures, diagrams, 
tables, charts, and other visual aids in reports; and entertaining queries and concerns of clients and customers regarding the products and services provided by the company $(\mathrm{M}=4.71)$; and 3. Comprehending verbal work instructions from supervisors and co-workers; discussing problems with others and offering solutions and feedback; and demonstrating ability to listen effectively $(\mathrm{M}=4.57)$.

Employers from business companies regarded the following to be the top communication skills in the workplace: 1 . Reading and comprehending letters and notices, electronic data, and emails (M=4.87); 2. Demonstrating ability to listen effectively $(\mathrm{M}=4.57)$; and 3. Reading and understanding work instructions and standard operating procedures $(\mathrm{M}=4.52)$.

Moreover, employers from engineering companies deemed these communication skills to be significant: 1 . Reading and comprehending letters and notices, electronic data, and emails $(\mathrm{M}=4.71) ; 2$. Comprehending verbal work instructions from supervisors and co-workers ( $\mathrm{M}=4.58)$; and 3. Demonstrating ability to listen effectively ( $\mathrm{M}=4.57)$.

Employers from education institutions considered these communication skills to be pertinent: 1. making use of pictures, diagrams, tables, charts, and other visual aids in reports $(\mathrm{M}=4.71)$; and 2. completing pertinent office forms, report sheets, tender documentation, work plans and specifications, incident report forms and notes; demonstrating skills in the use of language, grammar, and punctuation; reading and comprehending letters and notices, electronic data, and emails; and utilizing proper gestures and facial expressions when communicating orally $(\mathrm{M}=4.60)$.

On the other hand, employers from medical companies and institutions considered the following communication skills important: 1. Making use of pictures, diagrams, tables, charts, and other visual aids in reports $(\mathrm{M}=4.71)$; and 2. reading and comprehending letters and notices, electronic data, and emails ; participating in meetings and using interviewing skills to gather information or feedback ; reporting factual issues or incidents to the supervisor ; and speaking English clearly, fluently, and accurately ( $\mathrm{M}=4.67)$.

Lastly, other employers who do not belong in any of the above-mentioned types of companies, institutions, and organizations regarded the following communication skills to be important: 1. reading and comprehending letters and notices, electronic data, and emails; demonstrating ability to listen effectively; and participating in meetings and using interviewing skills to gather information or feedback $(M=4.67)$; and 2. Making use of pictures, diagrams, tables, charts, and other visual aids in reports $(\mathrm{M}=4.15)$.

Table3. Perceived Potent Communication Skills in the Workplace According to the Sector of Company/Institution/ Organization

\begin{tabular}{|c|c|c|c|c|}
\hline \multirow{2}{*}{ Communication Skill } & \multicolumn{2}{|c|}{ Government } & \multicolumn{2}{|c|}{ Private } \\
\hline & Mean & Rank & Mean & Rank \\
\hline $\begin{array}{l}\text { 1. Reading and understanding work } \\
\text { instructions and standard operating } \\
\text { Procedures }\end{array}$ & 4.39 & 2 & 4.54 & 2 \\
\hline $\begin{array}{l}\text { 2. Completing pertinent office forms, } \\
\text { report sheets, tender documentation, } \\
\text { work plans and specifications, } \\
\text { incident report forms and notes }\end{array}$ & 4.17 & 13 & 4.44 & 3 \\
\hline $\begin{array}{l}\text { 3. Comprehending verbal work } \\
\text { instructions from supervisors and } \\
\text { co-workers }\end{array}$ & 4.39 & 2 & 4.27 & 6 \\
\hline $\begin{array}{l}\text { 4. Discussing problems with others and } \\
\text { offering solutions and feedback }\end{array}$ & 4.22 & 8.5 & 4.22 & 8 \\
\hline $\begin{array}{l}\text { 5. Negotiating, bargaining, persuading, } \\
\text { and debating issues without being } \\
\text { unpleasant or abrasive to co-workers }\end{array}$ & 4.22 & 8.5 & 3.80 & 15.5 \\
\hline $\begin{array}{l}\text { 6. Demonstrating skills in the use of } \\
\text { language, grammar, and punctuation }\end{array}$ & 4.17 & 13 & 4.15 & 10 \\
\hline $\begin{array}{l}\text { 7. Organizing and presenting ideas } \\
\text { effectively for both formal and } \\
\text { spontaneous speeches }\end{array}$ & 4.22 & 8.5 & 4.00 & 12 \\
\hline $\begin{array}{l}\text { 8. Reading and comprehending } \\
\text { letters and notices, } \\
\text { electronic data, and emails }\end{array}$ & 4.26 & 4.5 & 4.59 & 1 \\
\hline $\begin{array}{l}\text { 9. Demonstrating ability to } \\
\text { listen effectively }\end{array}$ & 4.26 & 4.5 & 4.41 & 4 \\
\hline $\begin{array}{l}\text { 10. Participating in meetings and } \\
\text { using interv iew ing skills to gather } \\
\text { information or feedback }\end{array}$ & 4.22 & 8.5 & 3.63 & 20 \\
\hline
\end{tabular}




\begin{tabular}{|c|c|c|c|c|}
\hline \multirow[t]{2}{*}{ Communication Skill } & \multicolumn{2}{|c|}{ Government } & \multicolumn{2}{|c|}{ Private } \\
\hline & Mean & Rank & Mean & Rank \\
\hline $\begin{array}{l}\text { 11. Reporting factual issues or } \\
\text { incidents to the supervisor }\end{array}$ & 4.39 & 2 & 3.73 & 18 \\
\hline $\begin{array}{l}\text { 12. Utilizing proper gestures and } \\
\text { facial expressions when } \\
\text { communicating orally }\end{array}$ & 4.09 & 17 & 3.73 & 18 \\
\hline $\begin{array}{l}\text { 13. Understanding business, } \\
\text { computing, medical or engineering } \\
\text { lingo used in the workplace }\end{array}$ & 4.04 & 18 & 3.73 & 18 \\
\hline $\begin{array}{l}\text { 14. Writing appropriate forms of } \\
\text { business communication such as } \\
\text { letter, memorandum, report, } \\
\text { minutes of the meeting, plans, etc. }\end{array}$ & 4.13 & 15.5 & 3.93 & 14 \\
\hline $\begin{array}{l}\text { 15. Utilizing personal computer, multi- } \\
\text { mediafacilities, video, computer } \\
\text { graphics, projectors, devices, and } \\
\text { gadgets in communicating with } \\
\text { internal and external audiences }\end{array}$ & 3.83 & 20 & 4.10 & 11 \\
\hline $\begin{array}{l}\text { 16. Recognizing the benefits and } \\
\text { applications of memos, faxes, e-mails, } \\
\text { SMS, Internet to assist free-flowing } \\
\text { communication channels outside and } \\
\text { inside the organization }\end{array}$ & 4.13 & 15.5 & 4.20 & 9 \\
\hline $\begin{array}{l}\text { 17. Conducting research by gathering } \\
\text { information, interpreting data, and } \\
\text { presenting the results }\end{array}$ & 4.22 & 8.5 & 3.80 & 15.5 \\
\hline $\begin{array}{l}\text { 18. Making use of pictures, diagrams, } \\
\text { tables, charts, and other visual aids in } \\
\text { reports }\end{array}$ & 4.17 & 13 & 3.98 & 13 \\
\hline $\begin{array}{l}\text { 19. Entertaining queries and concerns } \\
\text { of clients and customers regarding the } \\
\text { products and services provided by the } \\
\text { company }\end{array}$ & 4.00 & 19 & 4.24 & 7 \\
\hline $\begin{array}{l}\text { 20. Speaking English clearly, fluently, } \\
\text { and accurately }\end{array}$ & 4.22 & 8.5 & 4.37 & 5 \\
\hline
\end{tabular}

Table 3 shows the perceived potent communication skills in the workplace according to the sector of company/institution/ organization where students are working or having their practicum/OJT. The communication skills which were regarded by government institutions to be significant are as follows: 1. reading and understanding work instructions and standard operating procedures; comprehending verbal work instructions from supervisors and co-workers; and reporting factual issues or incidents to the supervisor $(\mathrm{M}=4.39)$; and 2. Demonstrating ability to listen effectively; and demonstrating ability to listen effectively $(\mathrm{M}=4.26)$.

On the other hand, employers from private companies regarded the following communication skills to be highly significant: 1. reading and comprehending letters and notices, electronic data, and emails $(\mathrm{M}=4.59) ; 2$. reading and understanding work instructions and standard operating procedures $(\mathrm{M}=4.54)$; and 3. completing pertinent office forms, report sheets, tender documentation, work plans and specifications, incident report forms and notes $(\mathrm{M}=4.44)$. 
American Research Journal of English and Literature, Volume 1, Issue 5, 2015

ISSN 2378-9026

Table4. Differences on the Perceived Potent Communication Skills in the Workplace According to the Type of Company/Institution/Organization

\begin{tabular}{llcccc}
\hline & $\begin{array}{l}\text { Sum of } \\
\text { Squares }\end{array}$ & df & $\begin{array}{l}\text { Mean } \\
\text { Square }\end{array}$ & F & Sig. \\
\hline Between Groups & 5.129 & 5 & .744 & 1.2568 & .290 \\
Within Groups & 43.309 & 58 & .587 & & \\
Total & 48.438 & 63 & & \\
\hline
\end{tabular}

Table 4 shows that there is no significance difference between the perceived potent communications skills in the workplace according to the type of company/institution/ organization where the students are working or having their practicum/OJT. This means that the IT, business, engineering, education, medical, and other companies/ institutions/ organizations considered the same communication skills to be important in the workplace.

Table5. Differences on the Perceived Potent Communication Skills in the Workplace According to the Sector of Company/Institution/Organization

\begin{tabular}{lccccc}
\hline Category & N & Mean & df & F & Sig. \\
\hline Government & 23 & 4.39 & 62 & 5.159 & .459 \\
Private & 41 & 4.54 & & & \\
\hline
\end{tabular}

Table 5 depicts that there is no significant difference on the perceived potent communication skills in the workplace according to the sector of the company/institution/organization where students are working or having their practicum/OJT. This reveals that both the government and private companies/institutions/organizations deemed similar communication skills to be significant in the workplace.

\section{CONClusions}

Based on the findings, the following conclusions are drawn:

The top potent communication skills in the workplace are as follows: reading and understanding work instructions and standard operating procedures; reading and comprehending letters and notices, electronic data, and email; reporting factual issues or incidents to the supervisor; demonstrating ability to listen effectively and completing pertinent office forms, report sheets, tender documentation, work plans and specifications, incident report forms and notes.

There are no significance differences between the perceived communication skills in the workplace according to the type and sector of company /institution/ organization where students are working or having their practicum/OJT.

\section{REFERENCES}

[1] Bonilla, L. (2008). Workplace Skills for the $21^{\text {st }}$ Century in Orange County. Retrieved $\quad$ from http:// wplrc.com/app/doc/OC_Wp_Skills_Improvement(1).pdf on March 16, 2012

[2] Council Of Europe (2007) Guide for the Development of Language Education

[3] Policies in Europe. Main version (Strasbourg, Council of Europe, Language Policy Division) www.coe.int/ lang

[4] Csapo,N. and Featheringham, R. (2005). Communication Skills Used by Information Systems Graduates. Retrived from http://iacis.org/iis/2005/Csapo_Featheringham.pdf on March 12, 2013.

[5] Elan (2006) Elan: Effects on the European Economy of Shortages of Foreign Language Skills in Enterprise. December 2006. Report commissioned by the Directorate General for Education and European Commission. http://ec.europa.eu/education/policies/lang/doc/elan_en.pdf

Culture of the

[6] Maslen, G. (2008) foreign graduates fail job search, UniversityWorld News, 25.

[7] http://www.universityworldnews.com/article.php?story=20080522130029600 
American Research Journal of English and Literature, Volume 1, Issue 5, 2015

ISSN 2378-9026

[8] Robles, M. (2012).Executive Perceptions of the Top 10 Soft Skills Needed in Today's Workplace. Retrieved from http://bcq.sagepub.com/content/75/4/453.abstract on March 10, 2013.

[9] Smerd, J. (2007).Workforce Management. Retrieved from http://wplrc.com/app/doc/ OC_Wp_Skills_ Improvement (1). pdf on March 16, 2012.

[10] The Bologna Declaration (1999) the Bologna Declaration of 19 June 1999.

[11] Joint declaration of the European ministers of education. http://www.Bolognabergen 2005. No/Docs/ 00Main_doc /990719bologna_declaration.pdf 